https://doi.org/10.24026/1818-1384.4(64).2018.150168

\title{
ЗАСТОСУВАННЯ ХОЛЕКАЛЬЦИФЕРОЛУ В КОМПЛЕКСНІЙ ТЕРАПІЇ ДЛЯ КОРЕКЦЇ̈ ГІПЕРГЛІКЕМЇ̈ У ХВОРИХ НА ЦУКРОВИЙ ДІАБЕТ 2 ТИПУ
}

\author{
Т.П. Зарезенко, А.А. Жмур \\ Вінницький Національний медичний університет ім. М.І. Пирогова, кафедра \\ xipypziï №2.
}

Мета: визначення зв'язку рівня вітаміну Д з глікемічним статусом у хворих з цукровим діабетом 2 типу, ускладненим синдромом діабетичної стопи.

Матеріали і методи. В дослідженні прийняли участь 165 осіб, що не вживали додатково препарати вітаміну Д. 72 пацієнти дослідної групи хворіли на цукровий діабет 2 типу, 32 з них мали трофічні та гнійно-некротичні ускладнення синдрому діабетичної стопи (2 група), а інші 40 без ускладнень СДС (1 група). Контрольну групу склали 63 пацієнта.

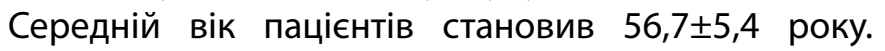
Хворим визначалися загальний рівень глюкози плазми крові, глікозильований гемоглобін $\left(\mathrm{HbA}_{1 \mathrm{c}}\right)$ та рівень 25 гідроксивітаміну Д $(25(\mathrm{OH}) \mathrm{D} 3)$ за загальноприйнятими біохімічними методиками. Всі пацієнти отримували лікування згідно стандартів, а в дослідній групі було додатково застосовано холекальциферол в дозі 4000 ОД щоденно протягом 60 днів з подальшою щоденною дозою 2000 ОД. Період спостереження склав 120 днів.

Результати і обговорення. Біохімічні аналізи виконувались при госпіталізації пацієнтів та на 120 добу після проведеного лікування. В ході дослідження було встановлено, що у пацієнтів контрольної групи не було ознак гіперглікемії натще, а рівень глюкози в плазмі крові натще при госпіталізації становив 4,61士0,42 ммоль/л, на відміну від дослідних груп, в яких рівень глюкози натще був

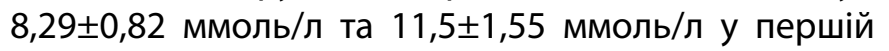
та другій групах відповідно. Після корекції терапії

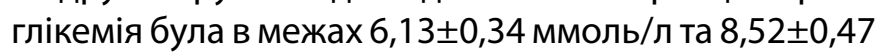
ммоль/л. Рівень $\mathrm{HbA}_{1 \mathrm{C}}$ в контрольній групі протягом дослідного періоду був 4,67士0,39\% , в дослідній -

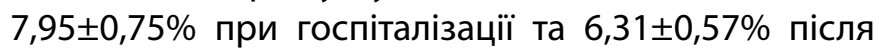
лікування. Рівень 25 гідроксивітаміну Дв контрольній групі був 33 33,33 нг/мл протягом всього періоду

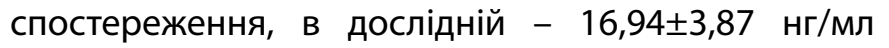

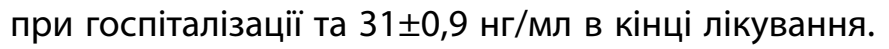
Встановлено зворотний кореляційний зв'язок між рівнями глікозильованого гемоглобіну та вітаміну
Д ( $r=-0,3336, p=0,046)$, що може свідчити про вплив вітаміну Д на регуляцію глікемії при цукровому діабеті 2 типу. У хворих з невеликим стажем хвороби та без діабетогенних ускладнень спостерігалась нормалізація глікемії під час досліду. Серед пацієнтів другої дослідної підгрупи був виявлений прямий зв'язок між ступенем дефіциту вітаміну Д та стадією виразкування. Під час застосування холекальциферолу в комплексному лікуванні відмічалась позитивна динаміка загоєння трофічних виразок у пацієнтів з синдромом діабетичної стопи.

Висновки. У хворих на цукровий діабет 2 типу, що не вживають на постійній основі полівітаміни, відмічається дефіцит та недостатність вітаміну Д. Встановлено зв'язок між глікемією та рівнем вітаміну Д, тому можна вважати, що вітамін Д впливає на корекцію глікемічного статусу при цукровому діабеті, а також дозволяє корегувати глюкозотолерантні стани.

Застосування вітаміну Д в комплексному лікуванні у хворих з цукровим діабетом 2 типу дозволяє покращити контроль над глікемією та в подальшому зменшити розвиток ускладнень.

\section{ЛІТЕРАТУРА}

1. Stratton IM, Adler Al, Neil HA, et al. Association of glycaemia with macro vascular complications of type 2 diabetes (UKPDS 35): prospective observational study. BMJ. 2000 Aug 12; 321(7258):405-12.

2. Mattila $C$, Knekt $P$, Mannisto $S$, Rissanen $H$, Laaksonen $M A$, et al. Serum 25-hydroxyvitamin D concentration and subsequentrisk of type 2 diabetes. Diabetes Care. 2007 Oct; 30(10):2569-70.

3. Norman AW, Frankel JB, Heldt AM, Grodsky GM. Vitamin $D$ deficiency inhibits pancreatic secretion of insulin. Science. 1980 Aug 15; 209(4458):823-5.

4. Holick MF. Vitamin D: a d-lightful solution for health. J Investig Med. 2011 Aug; 59(6):872-80.

5. Holick MF. Vitamin D status: measurement, interpretation, and clinical application. Ann Epidemiol. 2009 Feb; 19(2):73-8. 